Anais da Academia Brasileira de Ciências (2013) 85(1): 1-2

(Annals of the Brazilian Academy of Sciences)

Printed version ISSN 0001-3765 / Online version ISSN 1678-2690

www.scielo.br/aabc

\title{
Nanotechnology and lung diseases, caterpillars and agriculture, a new fossil turtle egg type from China, and a giant flying reptile from Gondwana
}

\author{
ALEXANDER W. A. KELLNER
}

Laboratório de Sistemática e Tafonomia de Répteis Fósseis, Departamento de Geologia e Paleontologia,
Museu Nacional/UFRJ, Quinta da Boa Vista, s/n, São Cristóvão, 20940-040 Rio de Janeiro, RJ, Brasil

This first issue of the Annals of the Brazilian Academy of Sciences (AABC) of the year has over 30 contributions in a variety of fields. Among the most interesting ones is a brief review of nanotherapy in the treatment of lung diseases presented by Adriana da Silva (Instituto de Biofísica Carlos Chagas Filho, UFRJ, Rio de Janeiro) and colleagues (Silva et al. 2013). Nanotechnology is being regarded as the future for several areas of scientific developments with a variety of applications, including pharmacotherapy. By manipulating substances on atomic and molecular scales, researchers see the potential for being able to treat diseases minimizing side effects (e.g., Bhaskar et al. 2010). Silva and colleagues review several aspects of published studies regarding the treatment of respiratory diseases, showing that there is still a wide gap between scientific results and clinical application in cases like asthma, tuberculosis and lung cancer.

Caterpillars belong to the order Lepidoptera, the same group of insects that includes butterflies and moths, some of which showing extreme beauty and thus with a special appeal to several people. However, caterpillars are also considered a nightmare for farmers around the globe. They are known for devastating plantations of several agricultural products such as tomatoes, soybean and even affecting the seedling production in forestry nurseries (e.g., Hallman 1979, Vázquez et al. 1999). Among the most voracious caterpillars is the species Spodoptera albula, which was identified in several regions of North, Central and South America (e.g., Pogue 2002), including Brazil (Zenker et al. 2010). Despite its importance due to its known great potential to harm farming, there are still several biological aspects of Spodoptera albula that are unknown. Débora Montezano (Universidade de Caxias do Sul, Rio Grande do Sul) and colleagues have established developmental parameters under controlled conditions by applying a new rearing method, which includes the employment of artificial diet, in order to obtain more information about their larval host plants (Montezano et al. 2013). Hopefully studies like this will help us to have a better understanding on the biological cycle of these insects and assist in the prevention of pests in agriculture.

Another interesting contribution published in the present number of the AABC is the discovery of a new chelonian fossil egg from China. Overall, fossil eggs are considered rare, particularly those laid by turtles, and only a very limited number has been recorded so far (e.g., Hirsch 1996, Jackson et al. 2008). Qiang Wang (Institute of Vertebrate Paleontology, Beijing, China) and colleagues discovered one chelonian egg in the deposits of Early Cretaceous age of the Laiyang Basin in the Shandong Province (Wang et al. 2013). These layers have furnished lots of fossil plant material, insects and also vertebrates, for all dinosaurs. 
Oddly, in several localities where these deposits crop out, eggs have been found and over 10 oospecies have been recognized. The material reported here represents a new type of chelonian egg and demonstrates that the ecosystem in this region was quite diverse during the Late Cretaceous.

Still talking about paleontology, the cover figure of this issue of the AABC portraits the cranial crest of a very unusual extinct flying reptile recovered from the Romualdo Formation (Lower Cretaceous) of the northeastern part of Brazil. Pterosaurs are rare, and despite the fact that remains of these volant vertebrates have been retrieved from several deposits around the world in the last decade, particularly from China (e.g., Jiang et al. 2011), most remains are quite fragmentary (e.g., O'Conner et al. 2011). The new specimen presented in this issue of the AABC had a wingspan of over $8 \mathrm{~m}$ and belongs to the largest flying reptile from any Gondwanan deposit known so far (Kellner et al. 2013). Most pterosaur specimens represent young animals, and fully ontogenetic developed individuals are quite rare, making this find even more interesting.

\section{REFERENCES}

BHASKAR S ET AL. 2010. Multifunctional nanocarriers for diagnostics, drug delivery and targeted treatment across blood-brain barrier: perspectives on tracking and neuroimaging. Part Fibre Toxicol 7: 3.

HALLMAN G. 1979. Importancia de algunas relaciones naturales plantas-artrópodos en la agricultura de la zona cálida del Tolima Central. Rev Colomb Entomol 5(3-4): 19-26.

HIRSCH KF. 1996. Parataxonomic classification of fossil chelonian and gecko eggs. J Vert Pal 16: 752-762.

JACKSON FD, Jin XS, VARRICCHIO DJ, AZUMA Y AND JIANG YG. 2008. The first in situ turtle clutch from Cretaceous Tiantai Basin, Zhejiang Province, China. J Vert Pal 28: 319-325.

JIANG S AND WANG X. 2011. A new ctenochasmatid pterosaur from the Lower Cretaceous, western Liaoning, China. An Acad Bras Cienc 83: 1243-1249.

Kellner AWA, CAmpos DAC, SAyão JM, SARaiva AAF, Rodrigues T, Oliveira G, Cruz LA, Costa FR, Silva HP AND FERREIRA JS. 2013. The largest flying reptile from Gondwana: a new specimen of Tropeognathus cf. T. mesembrinus Wellnhofer, 1987 (Pterodactyloidea, Anhangueridae) and other large pterosaurs from the Romualdo Formation, Lower Cretaceous, Brazil. An Acad Bras Cienc 85: 113-135.

Montezano DG, Specht A, Bortolin TM, Fronza E, Sosa-Gómez DR, Roque-Specht VF, Pezzi P, Luz PC and Barros NM. 2013. Immature stages of Spodoptera albula (Walker) (Lepidoptera: Noctuidae): developmental parameters and host plants. An Acad Bras Cienc 85: 271-284.

O'CONNER PM, SERTICH JJW AND MANTHI FK. 2011. A pterodactyloid pterosaur from the Upper Cretaceous Lapurr sandstone, West Turkana, Kenya. An Acad Bras Cienc 83: 309-315.

Pogue GM. 2002. A world revision of the genus Spodoptera (Guenée) (Lepidoptera: Noctuidae). Mem Am Entomol Soc 43: 1-202.

Silva AL, Santos RS, Xisto DG, Alonso SV, Morales MM and Rocco PRM. 2013. Nanoparticle-based therapy for respiratory diseases. An Acad Bras Cienc 85: 137-146.

VÁZQuez LL, MENÉNDEZ JM AND LóPEZ R. 1999. Manejo de insectos de importancia forestal en Cuba. Manejo Integrado de Plagas 54: $13-26$.

WAng Q, WAng X, Zhao Z, Zhang J And JiAng S. 2013. New turtle egg fossil from the Upper Cretaceous of the Laiyang Basin, Shandong Province, China. An Acad Bras Cienc 85: 103-111

Zenker MM, Botton M, Teston JA AND Specht A. 2010. Noctuidae moths occurring in grape orchards in Serra Gaúcha, Brazil and their relation to fruit-piercing. Rev Bras Entomol 54(2): 288-297. 